УДК 94(477.54)«20»

Анастасія Боженко,

кандидатка історичних наук,

старша викладачка кафедри українознавства філософського факультету

Харківського національного університету імені В. Н. Каразіна

a.o.bozhenko@karazin.ua

https://orcid.org/0000-0002-8701-6130

Олександра Суховєєва,

старша лаборантка кафедри українознавства філософського факультету,

студентка освітньо-професійної програми «Урбаністичні студії»

Харківського національного університету імені В. Н. Каразіна

osuhoveeva@karazin.ua

https://orcid.org/0000-0003-2907-0689

\title{
ЖИТИ У СОЦМІСТІ ЗАРАЗ : МІЖ СПАДЩИНОЮ ТА ОНОВЛЕННЯМ
}

У статті розглянуто проблеми участі місцевої громади у ревіталізаційних процесах, які відбуваються в історичному ареалі Соцміста, або району ХТЗ. Район було частково реалізовано у 1930-ті рр. за проєктом архітектора Павла Альошина. У післявоєнну добу від концепції Соцміста відмовилися, однак сам район і надалі розвивався як промзона. Було зведено низку нових потужних підприємств важкої промисловості. В сучасному контексті навіть за умов модернізації підприємств частина виробничих потужностей стає незатребуваною. 3 іншого боку, деіндустріалізацію потрібно розглядати у прив'язці до селітебної зони, тому в нашій статті ми фокусуємося на тих активістських ініціативах, які нині відбуваються у районі ХТЗ. Історіографія проблеми складається 3 досліджень історичного й містобудівного контексту, соціальної складової та теоретичних робіт із тематики індустріальної спадщини. Основа джерельної бази - дописи активістів у соціальній мережі «Фейсбук», містобудівна документація та законодавча база.

Ключові слова: ХТЗ, конструктивізм, індустріальна спадщина, активізм.

(c) Анастасія Боженко, Олександра Суховєєва, 2021 
1 Губкіна, Є. (2013). Проектування та реалізація «Новий Харків». Пам'ятки україни, 11. Retrieved from

https://www.alyoshin.ru/Files/publika/ gubkina/gubkina_novy_harkov.html; Черкасова, E. (2010). Идеи и реализация плана социалистической рекон-

струкции Харькова 1933-1935 годов. В Ю. Л. Косенкова (Ред.), Советское градостроительство 1920-1930- $x$ годов:

Новые исследования и материалы. Мо-

сква: Либроком. Retrieved from

http: //www.alyoshin.ru/Files/publika/4 erkasova/4erkasova 1933. html; Алешин,

В. Э. (1985). Развитие представления о социалистическом поселении в градостроительстве Украины в 1920-x начале 1930- $x$ годов. (Дис. на соискание ученой степени кандидата архитектуры). Киев. Retrieved from http: //www.alyoshin.ru/Files/ diss.html; Діденко, К. В. (2019).

Соиіально-житлові програми в архітектурі столичного Харкова (19171934 рр.). (Дис. на здобуття наукового ступеня кандидата архітектури) Харків. Retrieved from http://kstuca. kharkov.ua/wp-content/uploads/2019/09/ dd196denko-disser-2.pdf.

2 Любавський, Р. (2016). Повсякденне життя робітників Харкова в 1920-ті на початку 1930-x років. Харків.

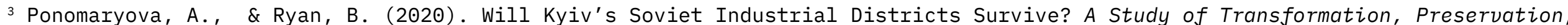
and Demolition of Industrial Heritage in Ukraine's Capital Journal of Planning History, 1 (49), 5-49; Пikepiнr, П., \& Бeprep,

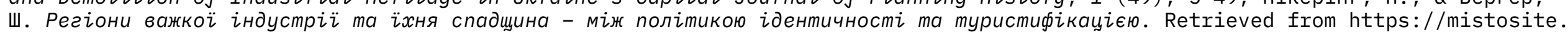
org.ua/ru/articles/rehiony-vazhkoi-industrii-ta-ikhnia-spadshchyna-mizh-politykoiu-identychnosti-ta-turystyfikatsiieiu.

4 юркова, 0. (2015). Facebook як

новий тип історичного джерела: спроба характеристики та практичні завдання архівування документів. Спеціальні історичні

дисиипліни: питання теорї̈ та методики, 25, 31-48.

Retrieved from http://nbuv.gov.ua/UJRN/sidptm_2015_25_4. сенс, який закладала радянська влада у побудову Соцміст, і прикладом таких досліджень $\epsilon$ монографія Романа Любавського ${ }^{2}$. Нарешті, згадаємо проблематику індустріальної спадщини у сучасному українському та світовому контексті ${ }^{3}$.

У джерельній базі дослідження процесів ревіталізації району головне місце посідають дописи активістів у соцмережах, які, на думку історикині Оксани Юркової, дають змогу «виявляти мережеві зв'язки, досліджувати історію формування громадських ініціатив та організацій, швидкість розповсюдження інформацї та ідей, iï/їх підтримку розвитку/неприйняття/заперечення тощо» 4 Також використано законодавчу базу щодо культурної спадщини та містобудівну документацію, зокрема історико-архітектурний опорний план Харкова, з метою дослідження статусу Соцміста як об'єкта культурної спадщини постіндустріальної економіки надзвичайно актуальними стають проблеми ревіталізаціі у зодів-велетнів. Увага радянських і заруХарківський тракторний завод. нашої теми. По-перше, це аналіз Соцміста містобудівного комплексу та розгляд 1 дивитися на той соціальний та ідеологічний на його проєктування ${ }^{1}$. По-друге, маємо . 
5 Губкіна, Є. Проектування та реалізація «Новий Харків».

6 Милютин, Н. (1930). Соuгород: Проблема строительства

соииалистических городов: Основные вопросы рациональной планировки и строительства населенных мест СССР. Москва; Ленинград: Государственное

издательство.

7 Алешин, В. Э. Развитие представления о социалистическом поселении.

8 Любавський, Р. (2020). «Місто Сонця район ХТЗ»: простір, образи, пам'ять. Вісник ХНУ. Серія «Історія», 57, 212226.

9 Див. детальніше про концепцію соціалістичного розселення: ХанМагомедов, С. Архитектура советского авангарда. Кн. 2. Социальные проблемы. Retrieved from https://www.alyoshin. ru/Files/publika/khan_archi/khan_

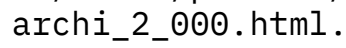

Puc. 1. Житловий комбінат (джерело: Проектирование и строительство соцгорода «Новый Харьков»,

\section{Історико-архітектурний контекст історії XT3}

Для сучасних харків'ян і харків’янок абревіатура ХТЗ асоціюється зі скороченою назвою не тільки Харківського тракторного заводу та станції Холодногірсько-заводської гілки метро, а й із цілим районом, розташованим у південно-східному напрямку від центру міста. Цей район і завод виникли у 1930-х рр під час форсованої сталінської індустріалізації. Після розрухи громадянської війни та років «паперової архітектури» в історії містобудування СРСР настав унікальний період. У 1920-1930-ті рр. в радянській архітектур склалися надзвичайно сприятливі умови для втілення у життя революційних ідей, концепцій та теоретичних побудов ${ }^{5}$. Провладний напрям розвитку країни спричинив утворення нового соціального запиту - потребу в проектуванні та зведенні соціалістичних поселень ${ }^{6}$. Для реалізації такого плану найкращою було визнано планову забудову, що також розширювало можливості застосування концептуального підходу у містобудуванні.

В архітектурній періодиці УРСР у цей час актуалізується ідея міста-саду Ебенізера Говарда та ідея міст-супутників; тривають дискусії щодо питань лінійного планування, вертикальної та горизонтальної забудови, урбанізації та дезурбанізації, культурної централізації та децентралізації, висувають ідеї функціонально диференційованого планування ${ }^{7}$.

Харківський історик Роман Любавський досліджує, як змінювалось із часом сприйняття району ${ }^{8}$. Задуманий як поселення типу соцмісто подібно до інших сучасних йому («Червоний Жовтень», «Червоне містечко», «Нова Горлівка», «Культурна революція», «Новий побут» та ін.), він мав назву «Новий Харків», що маркувала його як соціалістичне поселення та концептуально протиставляла старому, «буржуазному» Харкову. Будівництво розпочалося у 1930 р. та велося за принципом житлових комбінатів (зокрема концепцію обговорювали в рамках другої містобудівної дискусії 1929-1930рр.) ${ }^{9}$, які поєднували житлову та соціальну інфраструктуру (див. рис. 1).

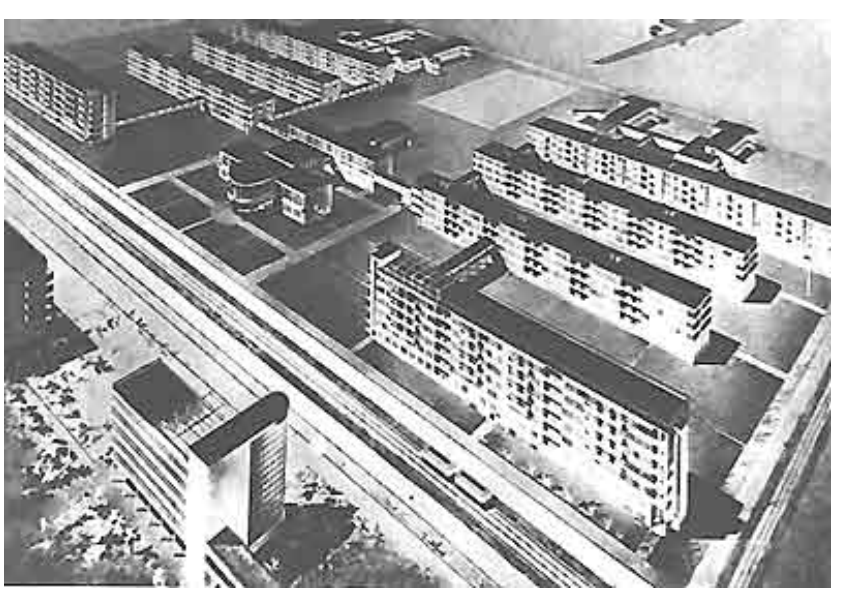




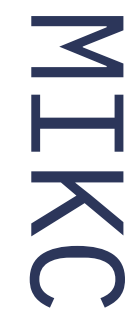

בט

Puc. 2. Соцмісто на історико-архітектурному опорному план (джерело: https://rive.google.com/drive/folders/ 1HAw8uEz9dppZpohVGRn96PO5K6zyLFeV)

10 Історико-архітектурний опорний план Харкова. Retrieved from https://drive. google.com/drive/folders/1HAw8uEz9dppZ pohVGRn96P05K6zyLFeV.

11 Алешин, В. Э. Развитие представления о социалистическом поселении.

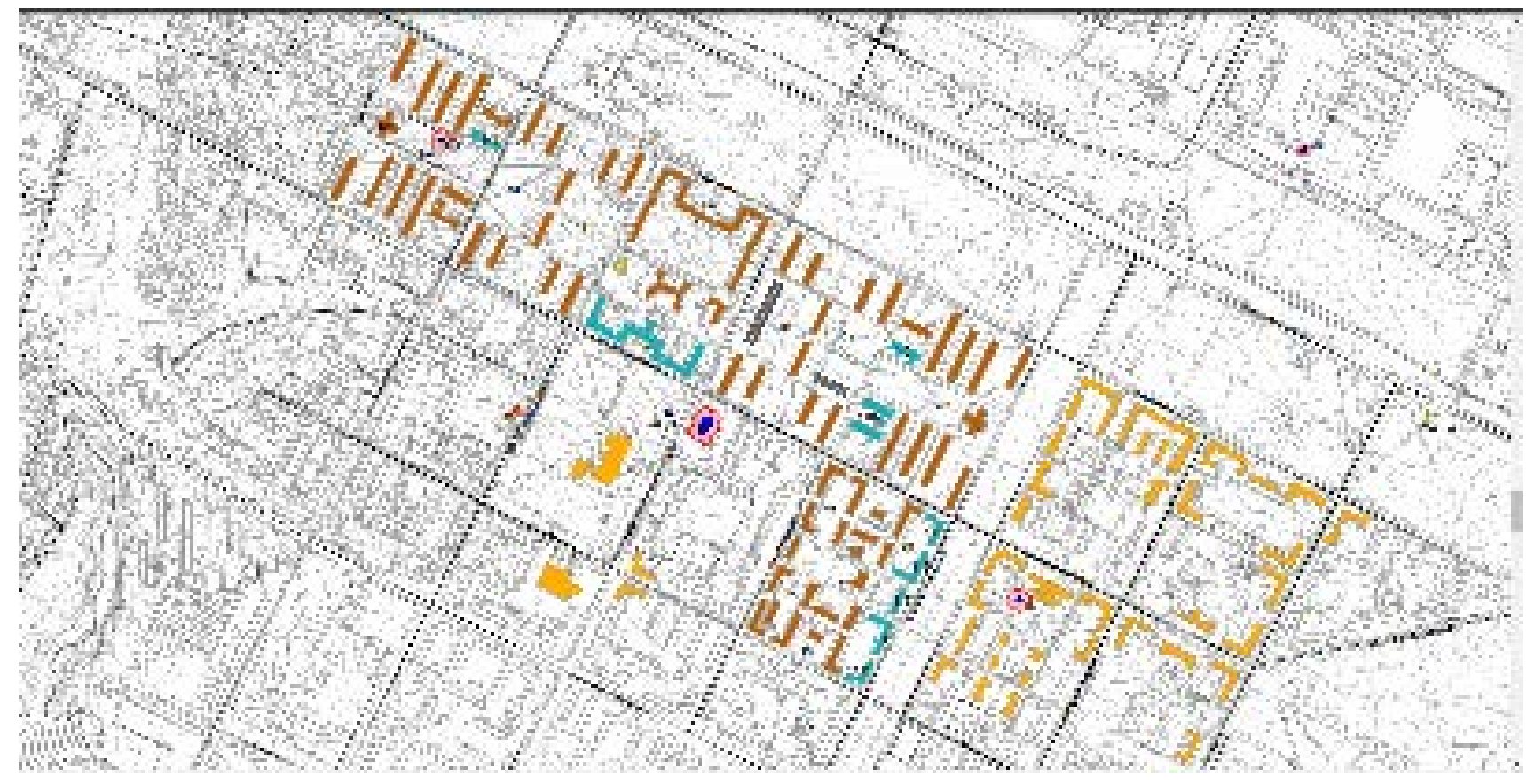

У післявоєнний час від цієї концепції відмовилися, але структура двох містобудівних комбінатів простежується на плані ХT3 і в сучасному місті ${ }^{10}$ (див. рис. 2).

Соцмісто спочатку було спроєктовано на відстані 7 км від тогочасних міських рубежів, і лише із побудовою у 1960-1970-х рр. району Нових будинків було приєднано до міста. Проєкт враховував ідеї міста-саду, функціонально диференційованого та лінійного планування, децентралізації культури. Під час проєктування Соцміста велику увагу приділяли озелененню: було передбачено внутрішньоквартальні насадження, чимало санітарних зелених зон і парк культури та відпочинку. Було забезпечено соціально-побутові й культурні потреби мешканців (без необхідності полишати для цього межі району); житлові квартали розташовувалися вздовж Чугуївської траси в безпосередній близькості від містоутворювального підприємства - ХТЗ ${ }^{11}$.

Потрібно підкреслити, що всі ці та інші позитивні риси соцміст (навіть такі, як витворення естетично привабливого архітектурного цілого малими засобами та чималі 

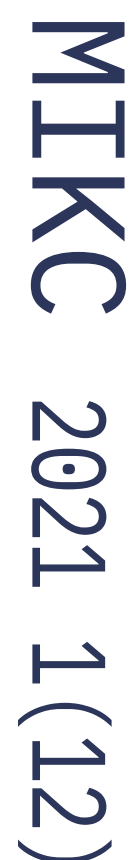

12 Иконников, А. В. (2001). Архитектура XX века. Утопии и реальность (Т. 1). Москва: Прогресс-Традиция, 275-343. «зелені» території) мали утворювати єдність промислового підприємства, мешканців-робітників і простору, функцією якого було якнайліпше сприяння виконанню завдань швидкої індустріалізації країни в першій п’ятирічці. Надаючи характеристику радянської доби, історик архітектури Андрій Іконніков відносить роки зведення «Нового Харкова» до періоду «преобладания осуществляемых прогрессистских утопий архитектурного авангарда» ${ }^{12}$.

Соцміста стають простором для спроб соціального конструювання засобами містопланування, архітектури та усуспільненої системи обслуговування побутових і культурних потреб. У цей період радянський теоретик архітектури Микола Мілютін писав свою книжку, що є всебічним збірником директив із планування та облаштування соціалістичних міст. Він неодноразово наголошував на тому, що замість того, щоб закріплювати старий спосіб життя, містопланувальники мають створювати умови для «народження нового побуту». В такому підході Мілютін убачав можливість звільнити тисячі нових рук для промисловості й підвищити ефективність робітників на підприємствах: «Советский поселок должен строиться таким образом, чтобы он не закреплял на многие годы те бытовые формы, с которыми мы ведем борьбу, а создавал предпосылки к организации нового, социалистического коллективного быта».

Як зазначає Роман Любавский, єдиної загальнообов'язкової моделі соцміст не склалося, була радше матриця із властивих їм рис. Що ж до «Нового Харкова», то цей район мав і такі риси соцміста, що були повноцінною частиною початкового проекту, але через певні обставини залишились на папері (селище ХTЗ не було винятком, часткова реалізація стала характерною рисою тогочасних архітектурних проектів), і такі, що їх було реалізовано у процесі зведення поселення. Через першочерговість завдань пришвидшеної індустріалізації не вистачало коштів на втілення проекту соцміста в повному обсязі. Навіть половини із запланованих 36 житлових комбінатів (кожен розраховано на розселення 2730 осіб, крім власне житлових площ мали побудувати ясла, дитсадок, їдальню, клуб, школу) не було зведено. Упродовж десятиліть залишалось нереалізованим заявлене у проекті будівництво другої черги - адміністративно-культурного центру (з будівлями міськради, палаців культури, фізкультури та праці, театру, стадіону, місцем для зібрань у вигляді амфітеатру), санаторію, парку культури та відпочинку та запланованих у зеленій смузі кінотеатру, музею, готелей. 


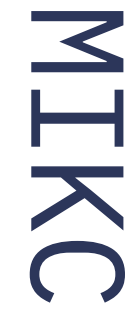

בטיָ

Рис. 3. Розташування промислових підприємств промзони.

Складено авторками (https://www.google.com/ maps/d/u/0/edit?mid=1gY_87PLEYSzNP-z IcGThFQ9kTzdj $\overline{2}$ yy\&usp=sharing)

13 Історико-архітектурний опорний план Харкова; мКмС: Затверджено межі та режими використання зон охорони пам'яток та історичного ареалу м. Харків. Retrieved from https://www.

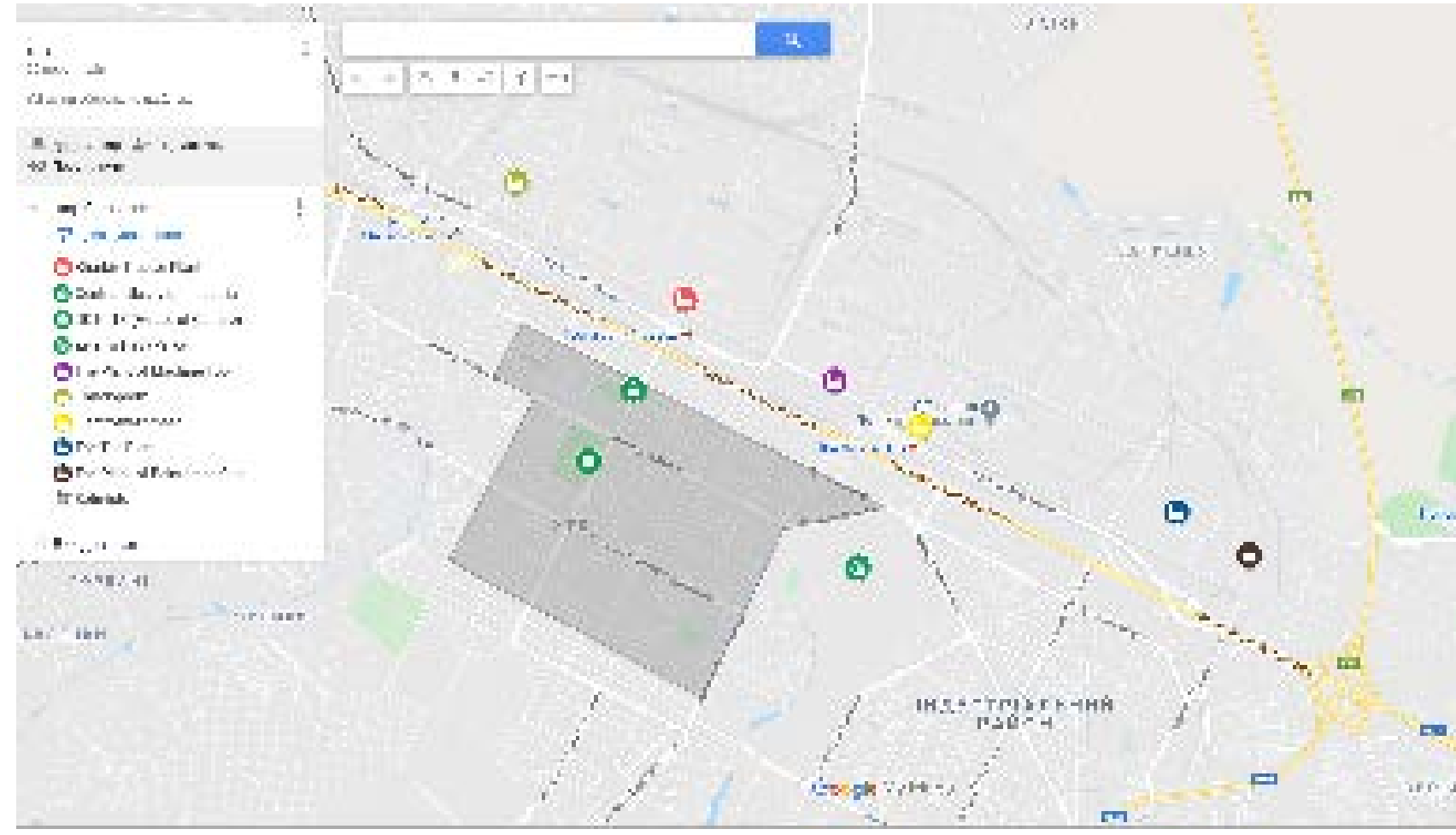

\section{Перспективи Соцміста у (пост) індустріальному контексті}

У наш час район важливий як архітектурна спадщина конструктивізму та сталінського ампіру, а також із погляду містобудівної структури. На історико-архітектурному опорному плані Харкова Соцмісто виділено як історичний ареал ${ }^{13} .3$ іншого боку, це індустріальна спадщина, оскільки окрім колишнього містоутворювального підприємства
ХТ3 поряд розташовані заводи післявоєнного часу (див. рис. 3). Ця промзона плавно переходить у Балашовську, де діє низка важливих для тканини міста підприємств (завод імені В. Малишева, завод холодильних машин, Харківський електромеханічний завод тощо). Зараз ці промзони перебувають у депресивному стані, пов'язаному зокрема 3 тим, що містобудівні підприємства або не працюють, або працюють частково.

Харківський дослідник Дмитро Чорний зауважує, що така проблема загалом 


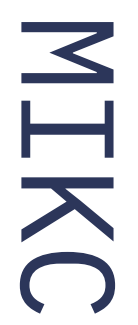

Puc. 4. Приклад конструктивістського об'єкта що зараз перебуває під загрозою спотворення. Це колишня фабрика-кухня, яка була важливим елементом житлокомбінату та є важливим об'єктом конструктивістської спадщини. Фото Олесі Чаговець

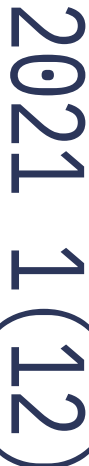

14 Ми свідомі того, що використання терміна «постіндустріальне

суспільство» $€$ дискусійним щодо

українських реалій, проте розкриття цього питання потребує окремої

теоретичної розвідки, тому не будемо зупинятися на ньому в цій статті.

15 Чорний, Д. М. (2018). Харків як об'єкт урбаністичних студій:

контексти, підсумки, нові орієнтири.

Вісник Хну імені В. Н. Каразіна. Серія «Історія Украӥни. Украӥнознавство:

історичні та філософські науки», 26, 159.

16 Spinnerei. Retrieved from https://www.spinnerei.de/.

Рис. 5. Фонова забудова також становить інтерес, хоча вона вже не має початкового вигляду через металопластикові вікна або пофарбована у невластивий для стилю конструктивізму колір Фото Олесі Чаговець

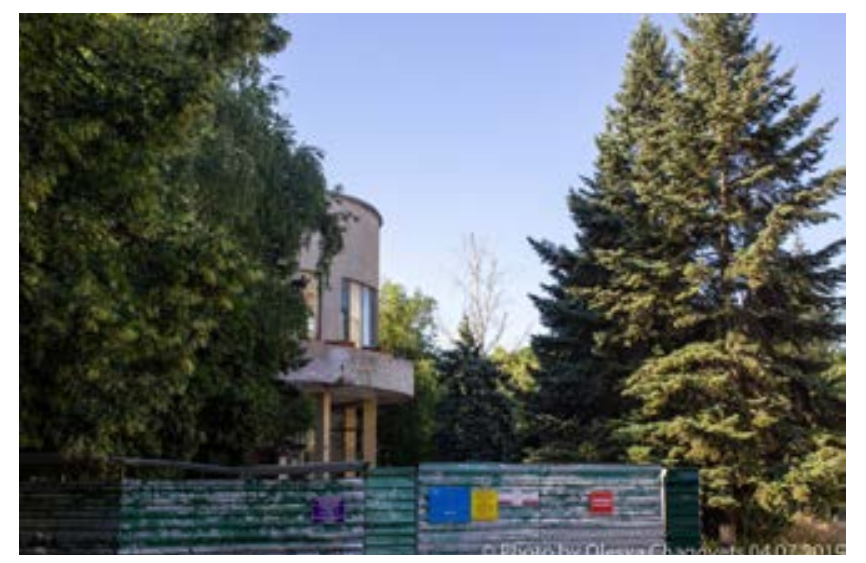

характерна для всіх постіндустріальних 14 суспільств, проте важливим є те, як іï розв'язують ${ }^{15}$. Можна згадати вдалий досвід Рурського регіону в Німеччині, де колишні промислові підприємства перетворюють на туристичні атракції, забезпечуючи робочими місцями тисячі людей. Інший шлях - це створення майданчиків для креативних індустрій, зокрема колишня бавовняна фабрика у Лейпцигу ${ }^{16}$.

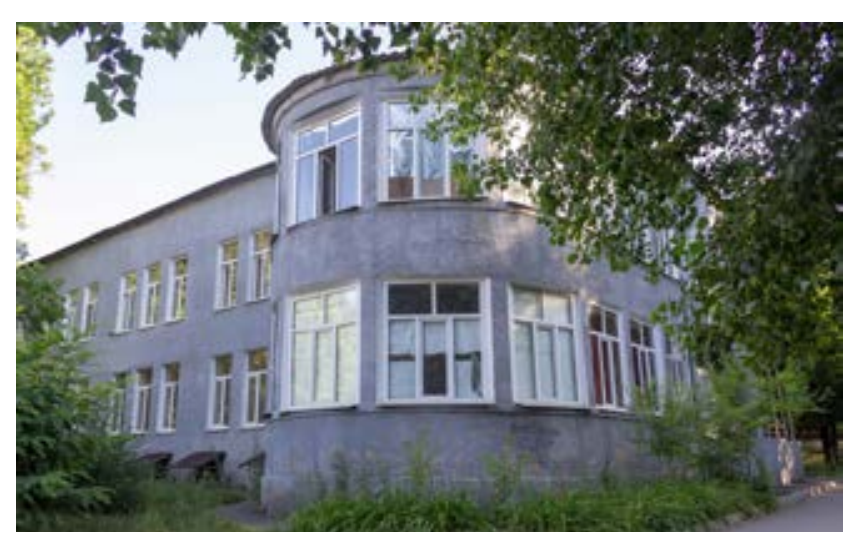

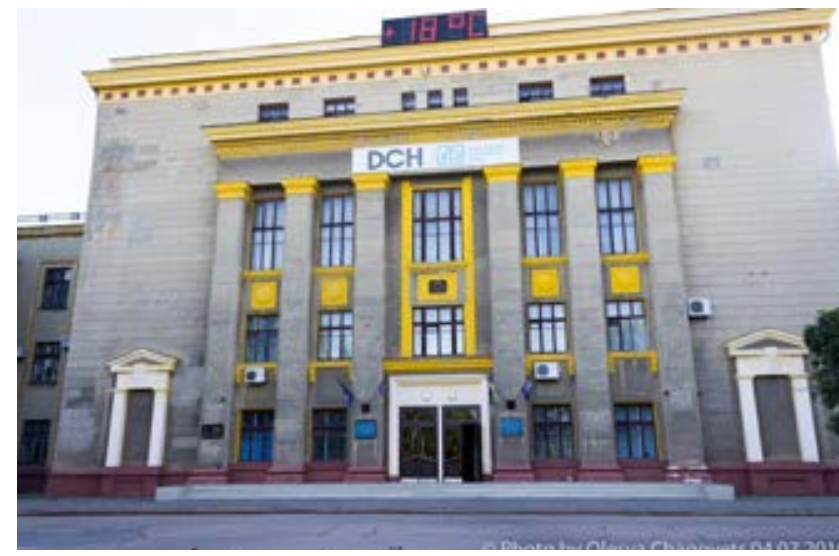

Рис. 6. Головна будівля заводу ХТЗ є пам’яткою архітектури у стилі ампір. Фото Олесі Чаговець

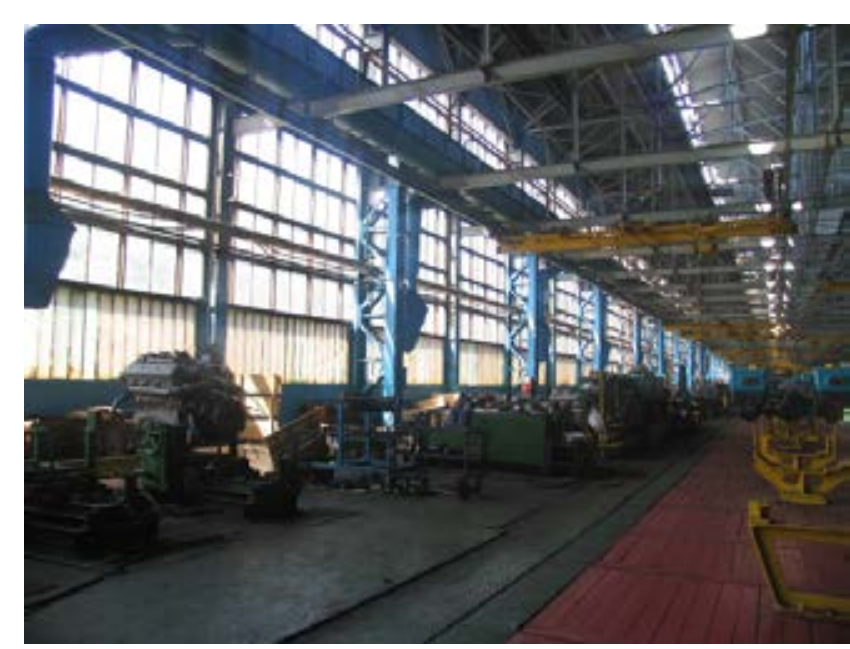

Pис. 7. Цех збірки тракторів ХТЗ, що функціонує нині. Фото Анастасії Боженко 
Рис. 8. Занедбана частина території заводу ХТЗ. Фото Анастасії Боженко

17 Харківський тракторний завод. Retrievsd from http://xtz.ua/ua/.

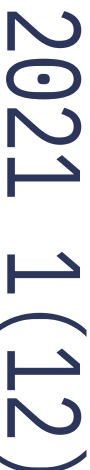

18 Пікерінг, П., \& Бергер, Ш. Регіони важкої індустрії.

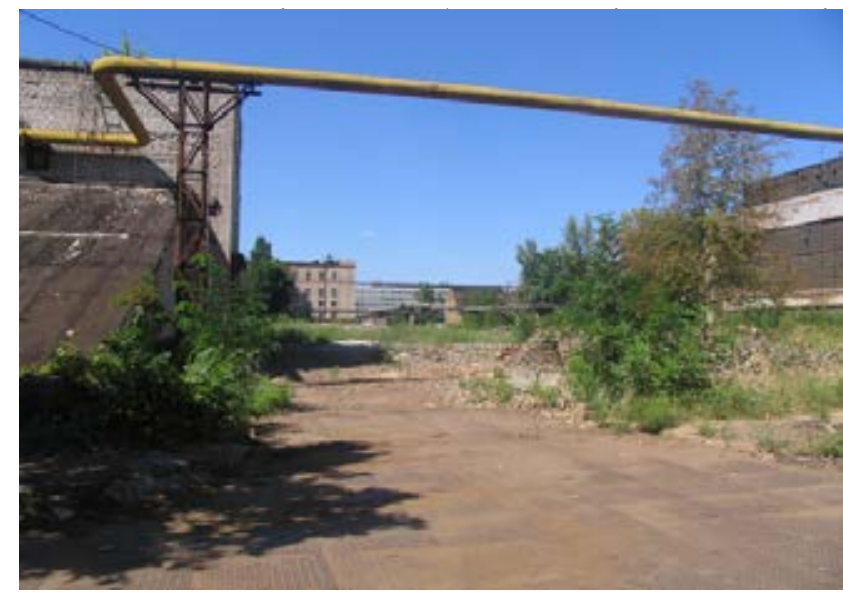

дуже великі об'єкти. Тож у постіндустріальну епоху індустріальна спадщина теж може бути потужним ресурсом для розвитку, а не тягарем. Якщо буде враховано позитивний досвід ревіталізацій індустріальних об'єктів (причому не лише самого об'єкта, а й територій, що його оточують), район ХТЗ і завод можуть потенційно стати точкою для розвитку міста.

Завод ХТЗ перебував у стагнації і не працював у 2015-2016 рр., нині виробництво тракторів запущено, однак, на відміну від радянського періоду, коли щороку випускали десятки тисяч тракторів, сьогодні ця кількість становить близько 600 тракторів на рік, тобто масштаби виробництва зменшилися у декілька десятків разів. На офіційному сайті заводу зазначено, що завдяки модернізації устаткування, яке постачають $з$ Японії та Нi- меччини, прибуток у 2019 р. зріс на 22 \% порівняно з минулим роком. Зараз на підприємстві працюють 1100 робітників. Продукцію експортують у країни пострадянського простору, Сингапур та Нову Зеландію ${ }^{17}$. Незважаючи на зростання попиту, виробництво не потребує таких величезних площ (зі 150 га задіяні лише 20 га, тобто більше ніж 87 \% території заводу не використовують).

3 іншого боку, в район приходять забудовники, 3'являються новобудови, що, певною мірою, є позитивним явищем, але водночас становить загрозу для культурної спадщини, адже порушується унікальна планувальна структура району, знищуються конструктивістські будівлі.

Професор університету у Бохумі Штефан Бергер згадує про різні моделі та акторів у ревіталізації індустріальної спадщини у світі. Зокрема, в Піттсбурзі (США), Ньюкаслі (Австралія), долині Жіу (Румунія) процес переважно відбувається через низові ініціативи, тоді як на півночі Франції цим активно займається держава ${ }^{18}$. Далі спробуємо проаналізувати ситуацію, яка склалася на ХТЗ.

3-поміж соціальних груп, які задіяні у процесі реновації, можемо виокремити декілька векторів і центрів. Передусім, це завод ХТЗ, головним власником якого з 2016 р. є харківський олігарх Олександр Ярославський, який відновив роботу заводу після стагнаціï. Нині під його керівництвом розробля- 
19 Экополис ХT3. Retrieved from https://www. ecopolishtz.com/ru/.

20 Група «Новий ХТ3» у соцмережі Facebook. Retrieved from https://www. facebook.com/groups/novyhtz/.

21 Допис у групі «Новий ХT3» FBкористувача @Борис Шестопалов від 12.05.2020. Retrieved from https:// www. facebook. com/groups/novyhtz/ permalink/4239175252821400.

22 Збереження та реконструкція парку «Зелений Гай». Retrieved from https://petition.city.kharkov.ua/ uk/3577.html. ють проєкт «Ecopolis HTZ» (High Technology Zone), який передбачає перетворення теритоpiї заводу, яка вже не працює за призначенням, на бізнес-центр, куди, крім виробництва входитимуть IT-кластер, медичний, освітній центри, агротехнологічний комплекс, інкубатор стартапів. Загальна територія комплексу становитиме 150 га, а приміщень - більше ніж 550 тис. кв. м. У проморолику проєкту зроблено акцент на надсучасних технологіях русі у майбутнє, також передбачено залучення іноземних інвесторів ${ }^{19}$.

Проте зауважимо, що у проєкті немає суттєвого зв'язку з розвитком району, поки що на сайті йдеться лише про територію самого заводу. Відповідно, рішення щодо долі заводу приймають одноосібно його власники, не залучаючи до цього громаду. Також непокоїть той факт, що немає зв'язку з пам'яттю про індустріальне минуле, адже, як свідчить проєкт, його ініціатори не дбають про збереження автентичності будівель; немає концепції музею, не проводиться жодних ініціатив зі збереження нематеріальної індустріальної спадщини. Тож наразі ми вбачаємо дві основні проблеми цього проєкту: брак відкритої інформації про дослідження інфраструктури району (отже, постає запитання, чи було враховано зростання навантаження на наявну соціальну, транспортну та комунальну інфраструктуру) та загроза знищення заводу як об’ єкта культурної спадщини.
Другим осередком оновлення став парк «Зелений гай», навколо якого гуртуються декілька активістських груп. Найчисельнішою 3-поміж них є ГО «Новий ХТЗ», постійні учасники якої - це приблизно 20-25 осіб, кількість підписників групи у Фейсбуці -4300 осіб ${ }^{20}$. Причому у складі групи $\epsilon$ не лише місцеві мешканці, а й люди з інших районів. До тактичних методів роботи групи належать прибирання парку та доведення його до ладу під час суботників, які проводять майже щотижня. Із серпня 2019 р. група також постійно організовує сімейні фестивалі з різноманітними заходами - майстер-класами 3 рукоділля, лекційною програмою, розвагами для дітей. Це перетворює парк на місце соціальної дії та допомагає залучати до руху нових мешканців ХТЗ (і не тільки, адже люди 3 інших районів теж приходять на ці події) ${ }^{21}$. Представники групи намагаються вести перемовини 3 місцевою владою, ініціюють петиції до міського голови ${ }^{22} .3$ одного боку, такі дії формують локальну спільноту, яка готова боротися за парк, створює певну ідентичність місця, 3 іншого - діям активістів іноді бракує експертного підходу, стратегічного планування, група діє на рівні тактичного урбанізму.

Окрім місцевих мешканців у район приходять і міські ГО та ініціативи. Приміром, «Рух за сталий розвиток» розробив свій план розвитку мобільної інфраструктури з метою 
${ }^{23}$ Група «ЕСОÏST» у соцмережі Facebook. Retrieved from https://www. facebook. com/groups/EKOICT.

24 Сторінка Г0 «Арт-оборона»у у соцмережі Facebook. Retrieved from https: //www. facebook.com/artoborona.

25 Допис у групі «Новий ХT3» FBкористувача QDmytro Skurikhin від 22.07.2020. Retrieved from https:// www. facebook. com/groups/novyhtz/ permalink/4551409288264660.

26 Допис у групі Новий Харків || Зелений Гай FB-користувача Руслан Аксьонов від 18.07.2020. 18 липня 2020 року. Парк «Зелений Гай». Retrieved from https://www. facebook.com/groups/593473914635005/ permalink/603351510313912/.

27 Сторінка ХОГО «Мир» у соціальній мережі Facebook. Retrieved from https://www. facebook.com/mir.kh.ua.

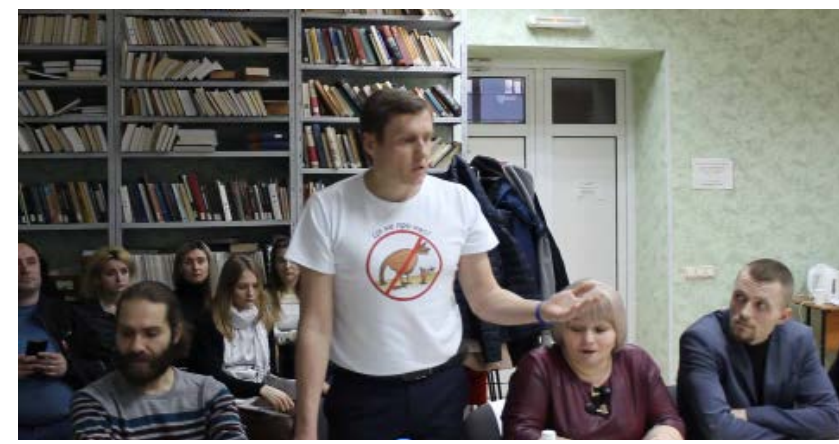

Puc. 9. Круглий стіл «Ревіталізація культурної спадщини Індустріального району міста Харкова як ресурс розвитку громади», 11 березня 2020 р Виступає голова ГО «Новий ХТЗ» Борис Шестопалов. Фото Олесі Чаговець

перетворення парку на повноцінну транзитну зону. Для популяризації занять спортом здорового способу життя передбачено зокрема обладнати бігові доріжки ${ }^{23}$.

ГО «Арт-оборона» регулярно долучається до фестивалів у Зеленому гаю, де поширює брошури з історичною довідкою про район, проводить воркшопи та майстер-класи, займається проблемами архітектурної спадщини. У березні 2020 р. було проведено круглий стіл, на якому зібралися активісти, експерти, представники влади та заводу 3 метою складання стратегії розвитку району (цю робота, на жаль, було загальмовано через карантин) ${ }^{24}$. Нині у планах ГО є подальше дослідження району як архітектурної та індустріальної спадщини (підготовка та зйомка документального фільму, написання науково-популярних матеріалів), проведення заходів щодо індустріальної спадщини.

У боротьбі за ХТЗ домінує екотематика, за допомогою якої активісти виборюють своє право на місто. Серед останніх подій оприлюднення концепції реконструкції парку департаментом комунального господарства та намагання ініціювати іiі громадське обговорення. Активісти окреслюють зокрема такі проблеми: юридично не закріплено межі парку «Зелений Гай», отже, є небезпека несанкціонованої забудови території; немає велоінфраструктури, належних умов для бізнесу ${ }^{25}$. Ще одна важлива тема для активістів - це відновлення русла ріки Студенок ${ }^{26}$ і припинення несанкціонованого вирубування дерев на околицях парку. На сьогодні така ситуація є унікальною для Харкова, адже в жодному іншому районі поки не спостерігаємо постійної активістської діяльності.

ХОГО «Мир» проводить тренінги та зустрічі, пропагує здоровий спосіб життя серед молодих людей, допомагає їм визначитися з професією, пропонує консультації психолога, надає можливість безкоштовної освіти для чутливих груп населення ${ }^{27}$. Ще одним осередком культурного оновлення стала Центральна бібліотека Індустріально- 
28 Сторінка Центральної бібліотеки Індустріального району імені А. П. Чехова. Retrieved from https:// www. facebook.com/BibliotekaChekhova.

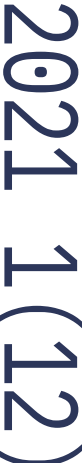

29 Adaptive reuse forum. Презентація результатів воркшопу «Dreaming up the KhTZ». Retrieved from https://youtu. be/LzL624Pkens.

30 Концепція парку Зелений гай: путівник з семи принципів сталого розвитку. Retrieved from https:// drive.google.com/file/d/1VU0pR8QIh3LVucYT7gmxbP6XB-uhf5L/view?fbclid=IwA R1Mw1EOjJTv34mP71bXhuV0A1mdsawqfoB4G5M h7n_1VLZVJQZ-ykJR96c.

31 Допис у групі ECOÏST користувача соціальної мережі Facebook @Andriy Malysha від 11.08.2020. Retrieved from https://www. facebook.com/groups/ го району імені А. П. Чехова, яка проводить різноманітні освітні заходи, зокрема на iі базі діє Український розмовний клуб ${ }^{28}$.

Також районом починають цікавитися дослідники (приміром, харківська школа архітектури проводила воркшоп «Dreaming up the XТЗ») ${ }^{29}$, митці (Open Place - проведення резиденцій), іноземні фонди (зокрема Фонд Конрада Аденауера), і це дає надію на акумулювання культурного та економічного капіталу, що, зі свого боку, виведе оновлення на новий рівень.

Окрім низки позитивних моментів, $\epsilon$ i проблеми. Зокрема, спостерігаємо розрізненість активістів і конфлікти між ними, бракує загальної стратегії та бачення, куди рухатися далі. Немає діалогу з місцевою владою та великим бізнесом; потрібно залучати експертів. I, зрештою, діяльність деяких груп політизується, через що виникають конфлікти на політичному грунті.

Активісти, згідно із сучасними екотенденціями, наголошують на необхідності переорієнтувати простори ХТЗ з індустріальних до постіндустріальних, тобто таких, що будуть запроектовані відповідно до концепції сталого розвитку. Активні члени місцевої громади обурені тим, що проблеми парку (немає туалетів, недостатнє освітлення, викиди сміття та нечистот у яр та джерело, наступ гаражів і новітньої забудови на рекреаційн

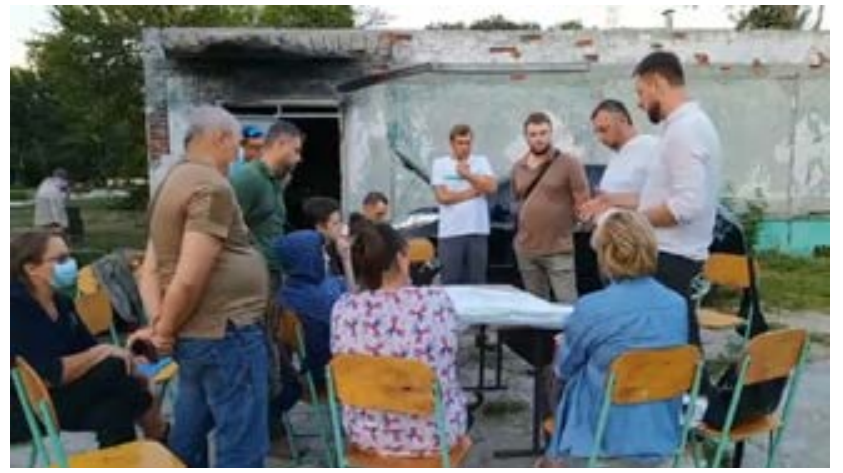

Рис. 10. Зустріч активістів ГО «Новий ХТЗ» iз представниками департаменту комунального господарства, обговорення плану реконструкції парку «Зелений гай», серпень 2020 p. Фото Дмитра Скуріхіна

території парку, неякісні роботи 3 реконструкції та озеленення парку, захаращення та засмічення території парку на околицях, брак історичної інформації про парк та ін.) довгий час залишаються нерозв'язаними. Зокрема, вони виступають за якнайповніше втілення розробленої проектувальною групою «Інший шлях» концепції ${ }^{30}$ перетворення парку «Зелений Гай»: «Ця концепція побудована на сучасних уявленнях про стійкий розвиток міського середовища, відповідає всім світовим трендам, а в чомусь і випереджає їх. Нагадуємо, що ми розглядаємо парк \#ЗеленийГай як центр району, який у майбутньому стане серцем міста - Нового Харкова, Міста Сонця» ${ }^{31}$. Під час спроби громадських обговорень проекту реконструкції 


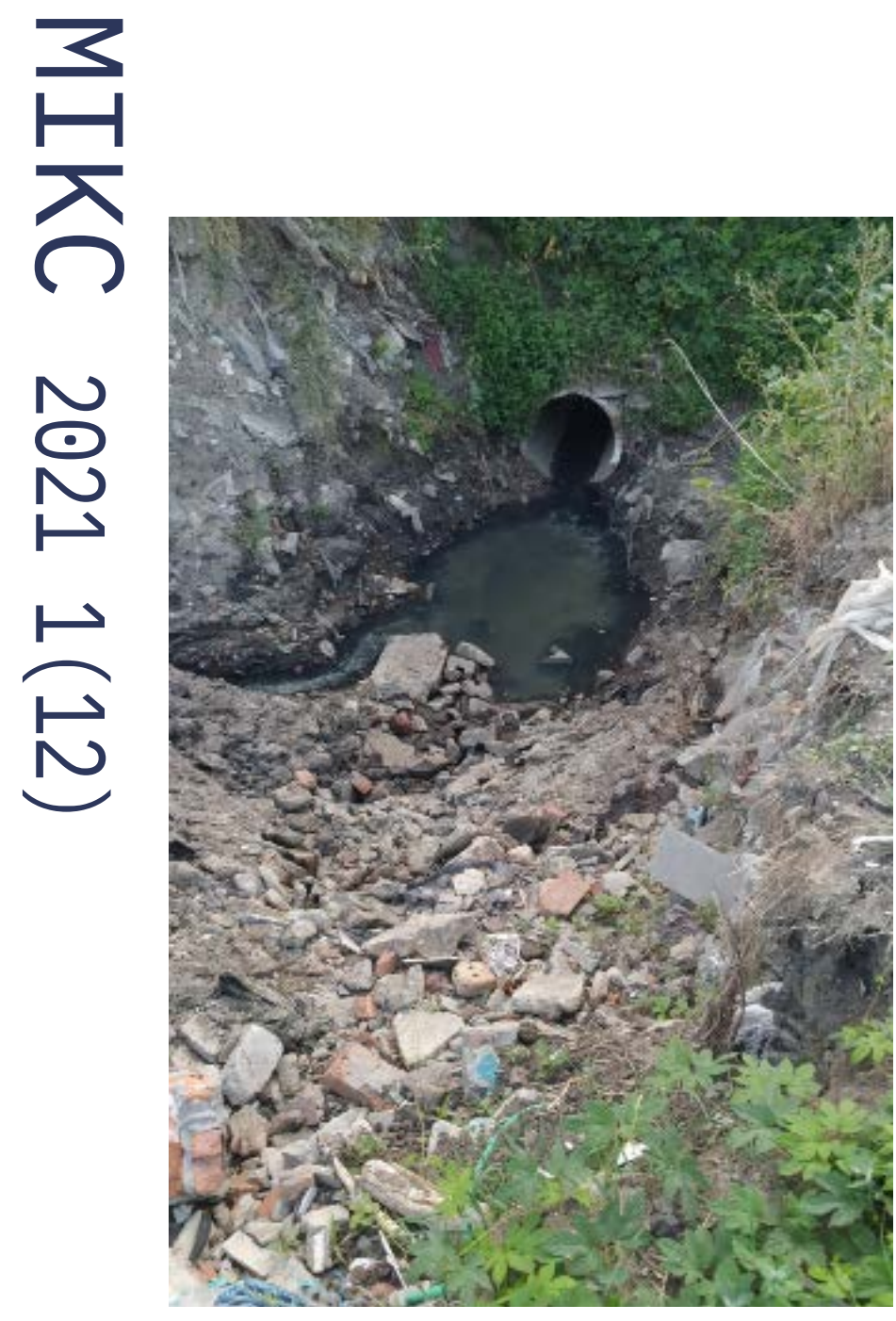

Puc. 11. Ділянка ймовірного русла р. Студенок, що межує з територією виправної колонії і куди постійно скидають сміття та нечистоти. Фото Руслана Аксьонова центральної частини парку «Зелений Гай» активісти також припустили можливість залучити до оновлення парку інший проект, який враховуватиме сучасні принципи сталого розвитку і так само передбачатиме створення каркасу зелених коридорів району та збереження біорізноманіття території.

\section{Висновки}

Отже, колишня промзона починає успішно реагувати на виклики деіндустріалізації. Оновлення йде як згори - через великий бізнес, так і знизу - за участю місцевих мешканців. Поки триває ревіталізація заводу, активні містяни намагаються створити свій публічний простір - парк «Зелений гай», який нині перебуває під загрозою забудови. Така активність приваблює зовнішні громадські організації, які розпочинають свої проєкти, що, знову ж таки, спрямовані на підвищення громадської активності. Прикметним при цьому $\epsilon$ те, що серед уявлень про таке оновлення чільне місце посідає вимога екологічності публічних просторів.

Зрештою, розглянувши наявні ініціативи, ми все одно ставимо запитання, яке потребує додаткового дослідження: чи наявний дискурс індустріальної спадщини серед акторів реновації? 3 одного боку, поняття інду- стріальної спадщини наразі законом не врегульовано, можливий лише статус пам'ятки науки і техніки. 3 іншого боку, у деклараціях і діях як активістів, так і великого бізнесу ми не бачимо сприйняття цього об'єкта як спадщини, прагнення зберегти його автентичність.

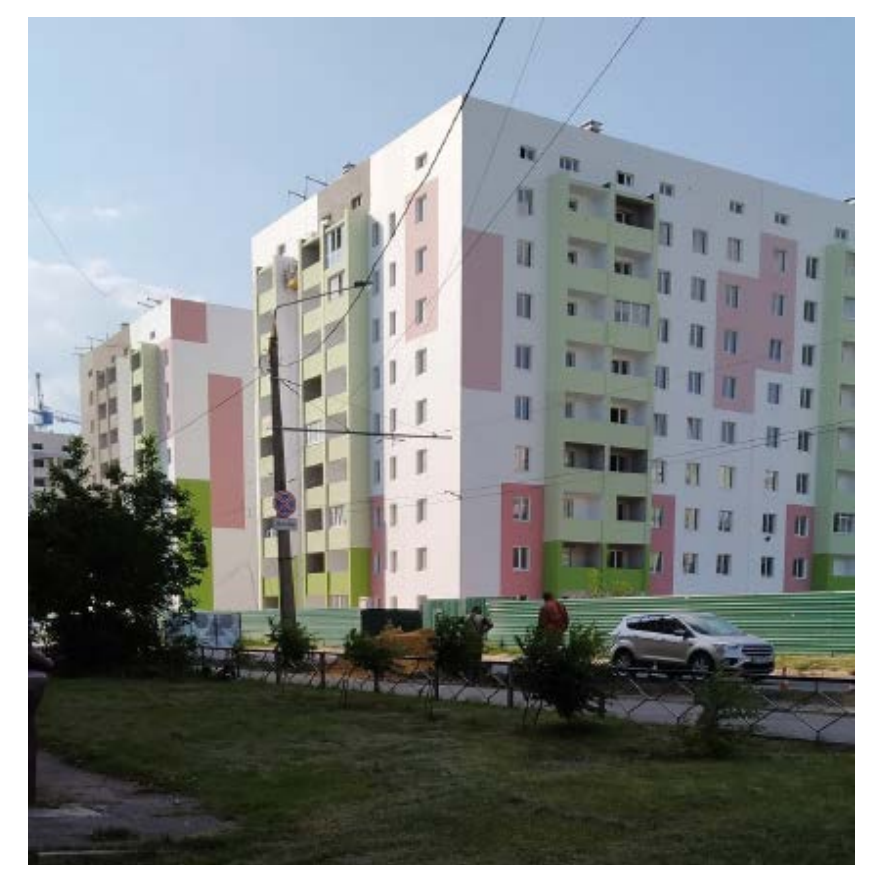

Puc. 12. Сучасна забудова по вул. Миру поблизу парку «Зелений гай». Фото Олександри Суховєєвої 


\section{References}

Adaptive reuse forum. Prezentatsiya rezul'tativ vorkshopu "Dreaming up the KhTZ". Retrieved from https://youtu.be/LzL624Pkens.

Aleshin, V. E. (1985). Razvitie predstavleniya o socialisticheskom poselenii $v$ gradostroitel'stve Ukrainy $v$ 1920-h-nachale 1930-h godov. (Dis. na soiskanie uchenoj stepeni kandidata arhitektury). Kiev. Retrieved from: http://www.alyoshin.ru/Files/diss.html [in Russian].

Cerkasova, E. (2010). Idei i realizaciya plana socialisticheskoj rekonstrukcii Har'kova 1933-1935 godov. In Yu. L. Kosenkova (Ed.), Sovetskoe gradostroitel'stvo 1920'1930-h godov: Novye issledovaniva $i$ materialy. Moskva: Librokom. Retrieved from http://www.alyoshin.ru/Files/publika/4erkasova/4erkasova_1933.html [in Russain].

Chornyy, D. M. (2018). Kharkiv yak ob'yekt urbanistychnykh studiy: konteksty, pidsumky, novi oriyentyry. Visnyk KhNU. Seriya "Istoriya Ukrayiny. Ukrayinoznavstvo: istorychni ta filosofs 'ki nauky”, 26, 157-164 [in Ukrainian].

Didenko, K. V. (2019). Sotsial'no-zhytlovi prohramy v arkhitekturi stolychnoho Kharkova (1917-1934 rr.) (Dys. na zdobuttya naukovoho stupenya kandydata arkhitektury). Kharkiv. Retrieved from: http://kstuca.kharkov.ua/wp-content/uploads/2019/09/dd196denko-diss er-2.pdf [in Ukrainain].

Group 'ECOÏST \|| EKOYiST' in social network 'Facebook'. Retrieved from https://www.facebook.com/ groups/EKOICT.

Group "Novyy Kharkiv | Zelenyy hay" in social network 'Facebook'. Retrieved from https://www.facebook.com/groups/593473914635005/.

Group "Novyy KhTZ" in social network 'Facebook'. Retrieved from https://www.facebook.com/ groups/novyhtz/.
Han-Magomedov, S. Arhitektura sovetskogo avangarda. Kn. 2. Social'nye problemy. Retrieved from https://www.alyoshin.ru/Files/publika/khan_archi/khan archi_2_000.html [in Russian].

Hubkina, Ye. (2013). Proektuvannya ta realizatsiya "Novyy Kharkiv". Pam 'iatky Ukrainy, 11. Retrieved from https://www.alyoshin.ru/Files/publika/gubkina/ gubkina_novy_harkov.html [in Ukrainain].

Ikonnikov, A. V. (2001). Arhitektura XX veka.Utopii i real'nost' (Vol. 1). Moskva: Progress-Tradiciya.

Il'chenko, M. (2018). Robitnychi poselennya yak ob'yekt sotsial'noyi inzheneriyi: nova rytoryka radyans'koyi epokhy. In V. Kulikova, \& I. Sklokinoyi, Pratsya, vysnazhennya ta uspikh: promyslovi monomista Donbasu (pp. 71-97). L'viv: FOP Shumylovych [in Ukrainian].

Istoriko-arhitekturnij opornij plan (grafika). Retrieved from https://drive.google.com/drive/folders/1HAw8uEz9dppZpohVGRn96PO5K6zyLFeV [in Ukrainian].

Jekopolis HTZ. Retrieved from https://www.ecopolishtz.com/ru/.

Kharkivs'kyy traktornyy zavod. Retrieved from http://xtz.ua/ua/.

Kontseptsiya parka Zelenyy hay: putivnyk z semy pryntsypiv staloho rozvytku. Retrieved from https:// drive.google.com/file/d/1VUOpR8QIh-3 LVucYT7 gmxbP6XB-uhf5L/view?fbclid=IwAR1MwlE0jJTv34mP71bXhuVOA1mdsawqfoB4G5Mh7n 1VLZVJQZ-ykJR96c.

Kozlova, I. (2016). Pravo na misto u suchasnykh ukrayins'kykh realiyakh: aktory ta shlyakhy realizatsiyi (pryklad L'vova). In Metodolohiya, teoriya ta praktyka sotsiolohichnoho analizu suchasnoho suspil'stva. Retrieved from http://er.ucu.edu.ua/handle/1/1032 [in Ukrainian]. 
Lyubavs'kyy, R. (2020). "Misto Sontsya - rayon KhTZ": prostir, obrazy, pam'yat'. Visnyk KhNU. Seriya "Istoriya", 57, 212-226 [in Ukrainian].

Lyubavs'kyy, R. (2016). Povsyakdenne zhyttya robitnykiv Kharkova v 1920-ti - na pochatku 1930-kh rokiv. Kharkiv [in Ukrainian].

Milyutin, N. (1930). Socgorod: Problema stroitel'stva socialisticheskih gorodov: Osnovnye voprosy racional'noj planirovki i stroitel'stva naselennyh mest SSSR. Moskva; Leningrad: Gosudarstvennoe izdatel'stvo [in Russian].

MKMS: Zatverdzheno mezhi ta rezhymy vykorystannya zon okhorony pam'yatok ta istorychnoho arealu m. Kharkiv. Retrieved from: https://www.mkip.gov.ua/ news/3709.html.

Note on the personal page of FB-user @Dmytro Skurikhin from 12.05.2020. Misto sontsya - rayon KhTZ, moyi sposterezhennya. Retrieved from https:// www.facebook.com/notes/dmytro-skurikhin/.

Note on the personal page of FB-user@Dmytro Skurikhin vid 13.08.2020. Zelenyy Hay, podiyi. Retrieved from https:/www.facebook.com/notes/dmytro-skurikhin/.

Page of Central'na biblioteka Industrial'nogo rajonu imeni A. P. Chexova. Retrieved from https://www.facebook.com/BibliotekaChekhova.

Page of GO "Art-oborona" in the social network 'Facebook'. Retrieved from https://www.facebook.com/ artoborona.

Page of the civil initiative "Syevyer zmin" in the social network 'Facebook'. Retrieved from https://www. facebook.com/severzminy.

Page of XOGO "My' $r$ " in the social network 'Facebook'. Retrieved from https://www.facebook.com/mir kh.ua.

Pikerinh, P., \& Berher, Sh. Rehiony vazhkoyi indus triyi ta yikhnya spadshchyna - mizh politykoyu identych- nosti ta turystyfikatsiyeyu. Retrieved from https://mistosite.org.ua/ru/articles/rehiony-vazhkoi-industrii-ta-ikhnia-spadshchyna-mizh-politykoiu-identychnosti-ta-turystyfikatsiieiu [in Ukrainian]

Ponomaryova, A., \& Ryan, B. (2020). Will Kyiv's Soviet Industrial Districts Survive? A Study of Transformation, Preservation, and Demolition of Industrial Heritage in Ukraine's Capital Journal of Planning History, 1 (49), 5-49.

Post in group "Novyy KhTZ" by FB-user $@$,Borys Shestopalov from 12.05.2020. Retrieved from https://www.facebook.com/groups/novyhtz/permalink/4239175252821400.

Post in group "Novyy KhTZ" by FB-user @ Dmytro Skurikhin from 22.07.2020. Retrieved from https://www.facebook.com/groups/novyhtz/permalink/4551409288264660.

Post in group ECOÏST of FB-user@Andriy Malusha from 11.08.2020 Retrieved from https://www.facebook com/groups/EKOICT/permalink/846094795794395.

Post in group "Novyy Kharkiv || Zelenyy Hay" by FB-user @,Andriy Malusha from 08.07.2020. Istoriya Zelenoho Hayu. Retrieved from https://www. facebook.com/groups/593473914635005/permalink/597044947611235/.

Post in group "Novyy Kharkiv || Zelenyy Hay" by FB-user@Ruslan Aks'onov from 18.07.2020. 18.07.2020. Park “Zelenyy Hay". Retrieved from https:// www.facebook.com/groups/593473914635005/permalink/603351510313912/.

Shlipchenko, S., Tymins'kyy, V., Makarenko, A. Males, L., \& Tyshchenko I. (Eds.). (2013). Misto y onovlennya. Urbanistychni studiyi. Predstavnytstvo Fondu im. Haynrikha Bollya v Ukrayini. Retrieved from https:// www.ua.boell.org/sites/default/files/urban_study2.pdf [in Ukrainian]

Spinnerei.from cotton to culture. Retrieved from https://www.spinnerei.de/. 
Verbyts'kyy, I. "Pravo na misto 2": yak onovlyuvaty misto, zberihayuchy pam'yatky. Retrieved from https:// mistosite.org.ua/articles/pravo-na-misto-2-iak-onovliuvaty-misto-zberihaiuchy-pamiatky?locale $=\mathrm{uk}$ Ukrainian].

Yurkova, O. (2015). Facebook yak novyy typ istorychnoho dzherela: sproba kharakterystyky ta praktych-

\section{Anastasiya Bozhenko, Oleksandra Sukhoveyeva}

\section{LIVING IN SOTSMISTO: BETWEEN HERITAGE AND DEVELOPMENT}

The article is devoted to the topical issues of developing the KhTZ district and the KhTZ plant as the object of the industrial heritage in the postindustrial society. The KhTZ district was created by famous Soviet architect and urban planner Pavlo Aloshyn as Sotsmisto, which could be opposed to the old Kharkiv and be built on the empty Losevo empty ground. The main element was the living cell, which contained housing and social infrastructure. In the arterwar time, this conception was left behind, although such an element is visible nowadays. The vast plants such as Electrovazhmash, the freezer plant, and the tile plant appeared. Now they do not work on their full production capacity and do not develop the social infrastructure. Nowadays, the KhTZ district, on the one hand, is the object of the architectural and industrial heritage.

On the other hand, it is considered a degrading district. In the district, there are several civil and cultural initiatives formed, and they advocate for the social, infrastructural and ecological development of the district. Thus, in this text, we will highlight the main actors of revitalization and their cross-points and conflicts.

Keywords: KhTZ, constructivism, activism, industrial heritage, tactical urbanism. 